WellBeing International

WBI Studies Repository

2013

\title{
Rating Harms to Wildlife: A Survey Showing Convergence between Conservation and Animal Welfare Views
}

\author{
S. Dubois \\ University of British Columbia \\ D. Fraser \\ University of British Columbia
}

Follow this and additional works at: https://www.wellbeingintlstudiesrepository.org/envncon

Part of the Animal Studies Commons, Natural Resources and Conservation Commons, and the Terrestrial and Aquatic Ecology Commons

\section{Recommended Citation}

Dubois, S., \& Fraser, D. (2013). Rating harms to wildlife: A survey showing convergence between conservation and animal welfare views. Animal Welfare, 22(1), 49-55.

This material is brought to you for free and open access by WellBeing International. It has been accepted for inclusion by an authorized administrator of the WBI Studies Repository. For more information, please contact wbisr-info@wellbeingintl.org.

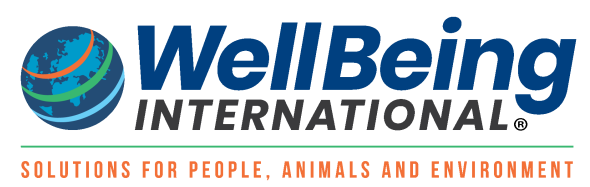




\title{
Rating Harms to Wildlife: A Survey Showing Convergence between Conservation and Animal Welfare Views
}

\author{
S. Dubois and D. Fraser \\ University of British Columbia
}

\begin{abstract}
KEYWORDS
animal welfare, conservation, harm, human activity, values, wildlife

ABSTRACT

Human activities may cause conservation concerns when animal populations or ecosystems are harmed and animal welfare concerns when individuals are harmed. In general, people are concerned with one or the other, as the concepts may be regarded as separate or even at odds. An online purposive survey of 339 British Columbians explored differences between groups that varied by gender, residency, wildlife engagement level and value orientation (conservation-oriented or animal welfareoriented), to see how they rated the level of harm to wildlife caused by different human activities. Women, urban residents, those with low wildlife engagement, and welfareorientated participants generally scored activities as more harmful than their counterparts, but all groups were very similar in their rankings. Activities that destroy or alter habitat (urban development, pollution, resource development and agriculture) were rated consistently as most harmful by all groups, including the most conservationoriented and the most welfare-oriented. Where such a high level of agreement exists, wildlife managers should be able to design management actions that will address both conservation and animal welfare concerns. However, the higher level of concern expressed by female, low engagement and welfare-oriented participants for activities that involve direct killing indicates a need for wildlife managers to consult beyond traditional stakeholders.
\end{abstract}

\section{Introduction}

Wildlife conservation and animal welfare share the common goal of preventing harm to wildlife, but the differences between these areas of concern have been a focus of much discussion. From the beginning, conservation science has set out to protect the integrity and continuity of natural processes, populations and ecological systems (Soulé 1985), whereas animal welfare science focuses on the quality of life of individuals (Fraser 2008). Further, conservation attaches special value to rare and keystone species that are important for biodiversity (Soulé 1985), whereas animal welfare applies to all sentient animals (Fraser 2008). Consequently, despite many areas of potential co-operation (Fraser 2010), conservation and animal welfare concerns are often seen as separate, being both politically and practically distinct (Soulé 1985; Fulton \& Ford 2001). 
Different wildlife value positions are particularly clear in ethical theory. On the one hand, Aldo Leopold's holistic, non-anthropocentric 'land ethic' values the beauty and integrity of biotic communities, and appears compatible with some harms to individual animals (culling, pest control) if these are needed for ecological purposes (Callicott 1989). In contrast, Regan's (1983) theory of animal rights claims inherent and equal value of all animals that meet his criterion for 'subjects-of-a-life', and holds that such animals should not be treated as resources or harmed in order to achieve other goals. Perhaps fearing the loss of wildlife recreation and research opportunities (Schmidt 1990), North America's largest wildlife professional association recently denounced animal rights in a position statement (The Wildlife Society [TWS] 2011). More compatible with conservation is an ethic of animal welfare (see Hutchins 2007), which seeks to promote animal health, prevent suffering, and allow animals to live in ways that suit their natural adaptations (Fraser 2008).

Nonetheless, a division between conservation and animal welfare is largely engrained in the professional practice of wildlife management. Government wildlife agencies generally work within conservation mandates and legislation that protect endangered and threatened species, preserve their habitats and maximise biodiversity (eg British Columbia Ministry of Environment 2011). Such policies may include narrow welfare considerations for 'humane' death and preventing 'harassment' to individuals of certain species (eg Government of British Columbia 2012a), but legal protection for the welfare of free-living wildlife is often limited (eg Government of British Columbia 2012b). The conflict between conservation and animal welfare is particularly apparent in controversial issues such as the control of feral cats (Longcore et al 2009) and non-native species (Perry \& Perry 2008), sport hunting (Curnutt 1996), and wildlife rehabilitation (Kirkwood \& Sainsbury 1996; Dubois \& Fraser 2003; Wimberger et al 2010).

Although these divisions exist in philosophy and professional practice, most people believe that animal pain and suffering should be reduced where possible (eg HarrisDecima 2010) and support the goal of preserving species biodiversity (Gallup 2010). However, it is less known how people perceive and rate human activities that harm wildlife when both conservation and animal welfare are involved. The goal of this research was to compare and explore how members of the public, including those with conservation versus animal welfare orientations, rate the importance of different activities that harm wild animals.

\section{Materials and methods}

Design

A wildlife values survey (WVS) was administered through the online engagement tool 'YourViews', which serves as a platform for surveys to explore attitudes about ethical issues in science and technology (Ahmad et al 2006). All YourViews' surveys require creation of a password-protected user profile which limits participation to once per survey and records demographics including gender, age category, education level, country of origin, and country of residence. Further mandatory demographics, specific to the WVS, included province of residence and urban or rural residency. Optional demographics asked participants about wildlife activities they enjoyed or supported, and any organisational memberships. Also, participants could indicate whether they were a wildlife professional (paid) or enthusiast (unpaid). Those that selected 'yes' to such formal involvement were then asked to identify the type of wildlife engagement, including the activity, their role, and their length of engagement.

Three open-ended lead-up questions on harmful activities to wildlife were asked to understand participants' views on global, local, and species-specific harms, respectively. Written responses were used to help establish the wildlife value orientation (described below) of participants. The main research question asked participants to score the level of perceived harm to wildlife ("in terms of overall number of animals impacted globally"), caused by 12 pre-defined human activities (Table 1) using a scale of 1 
(least) to 7 (greatest). 'Harm' was intentionally not defined in order to leave the interpretation up to respondents. These activities were selected as a diverse sample of activities broadly known to have significant but different effects on wild animals and populations (Sainsbury et al 1995; Dubois \& Fraser 2003; Woods et al 2003; Salafsky et al 2008; Massei et al 2010; Fraser \& MacRae 2011; Kuhnen et al 2012). An optional open-ended text box for comments allowed participants to explain their scores. Participants were not able to neither see scores or comments from other participants nor go backwards between pages to change their answers to a previous question.

Table 1. Definition of 12 human activities that harm wildlife (in order presented to participants).

\begin{tabular}{|c|c|}
\hline Activity & Definition \\
\hline Cat predation & $\begin{array}{l}\text { The death or injury of birds, small mammals, reptiles and amphibians by free-roaming } \\
\text { owned and unowned cats }\end{array}$ \\
\hline Urban development & The conversion of wildlife habitat to human habitat \\
\hline Poaching & $\begin{array}{l}\text { The illegal capture or killing of wild animals, which may lead to the transport and sale } \\
\text { of live animals or their parts or meat }\end{array}$ \\
\hline Road/Railroad kill & $\begin{array}{l}\text { The death or injury of wild animals during the approach or crossing of roads and } \\
\text { railroad lines }\end{array}$ \\
\hline Sport hunting & $\begin{array}{l}\text { Legal hunting of wild animals for recreation or in pursuit of a trophy, whether or not } \\
\text { any meat is taken for consumption }\end{array}$ \\
\hline Window strikes & $\begin{array}{l}\text { The death or injury of wild animals as a result of impact with buildings or structures } \\
\text { with reflective glass or which maintain lights at night }\end{array}$ \\
\hline Relocation & The capture and movement of wild animals from one habitat to another \\
\hline Resource development & Logging, mining, drilling or other activity in pursuit of non-animal resources \\
\hline Pest control & $\begin{array}{l}\text { The killing of any wild animal perceived to be a nuisance, the methods of which } \\
\text { (poison, traps, etc) may cause death or injury to other non-targeted animals }\end{array}$ \\
\hline Pet trade & The legal capture, transport and sale of wild animals as pets \\
\hline Pollution & The discharge of chemical pollutants into any water, air or soil system \\
\hline Agriculture & $\begin{array}{l}\text { The conversion and use of wildlife habitat to grow crops or raise livestock for food } \\
\text { production }\end{array}$ \\
\hline
\end{tabular}

\section{Recruitment}

The recruitment strategy was designed to explore and compare the views of British Columbians who were concerned primarily about wildlife conservation or primarily about animal welfare. Recruitment first targeted individuals with high levels of engagement with wildlife, either as a paid professional (eg biologist, manager, policymaker, guide outfitter, rehabilitator, veterinarian) or as an unpaid enthusiast (hunter, trapper, naturalist). This recruitment included direct emails to the British Columbia Wildlife Federation (a hunting and trapping organisation) and to wildlife professionals through government and nonprofit directories. Participants were also encouraged to disseminate the survey invitation to other British Columbian wildlife professionals and enthusiasts.

Further recruitment targeted members of the public in British Columbia with an interest in wildlife but low personal or professional engagement. This involved email solicitations in membership e-newsletters of the British Columbia Society for the Prevention of Cruelty to Animals, Vancouver Aquarium, Wildlife Rescue Association of British Columbia, and the Vancouver Humane Society. Members of these nonprofit organisations are generally donors and volunteers, who were considered to have lower engagement than staff working for such organisations. Direct emails to past YourViews' survey participants were also sent. Although available by open access on the internet, the survey link was only distributed by email and non- 
British Columbians were excluded from analysis. As recruitment was not random, the survey was intended to explore comparisons rather than provide a representative sample of the population.

Table 2. Mean ( \pm SEM) score of perceived harm to wildlife caused by 12 human activities on a scale of 1 (least harm) to 7 (greatest harm), and results of hierarchical regression analysis ${ }^{\mathrm{a}}$ and Spearman rank-order correlation ${ }^{\mathrm{b}}$.

\begin{tabular}{|c|c|c|c|c|c|c|c|c|c|c|}
\hline \multirow[t]{2}{*}{ Activity } & \multicolumn{2}{|c|}{ Gender } & \multicolumn{2}{|c|}{ Residency } & \multicolumn{2}{|c|}{$\begin{array}{c}\text { Wildlife } \\
\text { engagement level }\end{array}$} & \multicolumn{2}{|c|}{$\begin{array}{l}\text { Wildlife value } \\
\text { orientation }\end{array}$} & \multicolumn{2}{|c|}{$\begin{array}{c}\text { Strong wildlife value } \\
\text { orientation }\end{array}$} \\
\hline & $\begin{array}{l}\text { Female } \\
(n=229)\end{array}$ & $\begin{array}{c}\text { Male } \\
(n=105)\end{array}$ & $\begin{array}{l}\text { Urban } \\
(n=227)\end{array}$ & $\begin{array}{l}\text { Rural } \\
(n=112)\end{array}$ & $\begin{array}{c}\text { Low } \\
(n=227)\end{array}$ & $\begin{array}{l}\text { High } \\
(n=112)\end{array}$ & $\begin{array}{l}\text { Animal } \\
\text { welfare } \\
(n=147)\end{array}$ & $\begin{array}{l}\text { Conservation } \\
(n=192)\end{array}$ & $\begin{array}{c}\text { Animal } \\
\text { Welfare }^{c} \\
(n=11)\end{array}$ & $\begin{array}{c}\text { Conservation }^{d} \\
(n=22)\end{array}$ \\
\hline $\begin{array}{l}\text { Urban } \\
\text { development } \\
\left(R^{2}=0.081\right)\end{array}$ & $\begin{array}{c}6.8 \\
( \pm 0.04)\end{array}$ & $\begin{array}{c}6.3 \\
( \pm 0.11)^{\star \star}\end{array}$ & $\begin{array}{c}6.7 \\
( \pm 0.05)\end{array}$ & $\begin{array}{c}6.5 \\
( \pm 0.09)\end{array}$ & $\begin{array}{c}6.7 \\
( \pm 0.05)\end{array}$ & $\begin{array}{c}6.5 \\
( \pm 0.10)\end{array}$ & $\begin{array}{c}6.8 \\
( \pm 0.05)\end{array}$ & $6.5( \pm 0.07)$ & $\begin{array}{c}6.8 \\
( \pm .12)\end{array}$ & $6.0( \pm 0.32)$ \\
\hline $\begin{array}{l}\text { Pollution } \\
\left(R^{2}=0.112\right)\end{array}$ & $\begin{array}{c}6.4 \\
( \pm 0.07)\end{array}$ & $\begin{array}{c}5.8 \\
( \pm 0.13)^{\star}\end{array}$ & $\begin{array}{c}6.3 \\
( \pm 0.07)\end{array}$ & $\begin{array}{c}6.0 \\
( \pm 0.12)\end{array}$ & $\begin{array}{c}6.4 \\
( \pm 0.06)\end{array}$ & $\begin{array}{c}5.7 \\
( \pm 0.13)^{\star \star}\end{array}$ & $\begin{array}{c}6.4 \\
( \pm 0.08)\end{array}$ & $6.0( \pm 0.09)$ & $\begin{array}{c}6.4 \\
( \pm 0.24)\end{array}$ & $5.3( \pm 0.34)^{\star \star}$ \\
\hline $\begin{array}{l}\text { Resource } \\
\text { development } \\
\left(R^{2}=0.090\right)\end{array}$ & $\begin{array}{c}6.2 \\
( \pm 0.07)\end{array}$ & $\begin{array}{c}5.5 \\
( \pm 0.16)^{\star \star}\end{array}$ & $\begin{array}{c}6.1 \\
( \pm 0.08)\end{array}$ & $\begin{array}{c}5.7 \\
( \pm 0.15)\end{array}$ & $\begin{array}{c}6.2 \\
( \pm 0.08)\end{array}$ & $\begin{array}{c}5.5 \\
( \pm 0.14)^{\star \star}\end{array}$ & $\begin{array}{c}6.1 \\
( \pm 0.10)\end{array}$ & $5.8( \pm 0.10)$ & $\begin{array}{c}6.4 \\
( \pm 0.31)\end{array}$ & $4.3( \pm 0.40)^{\star \star}$ \\
\hline $\begin{array}{l}\text { Agriculture } \\
\left(R^{2}=0.058\right)\end{array}$ & $\begin{array}{c}5.9 \\
( \pm 0.09)\end{array}$ & $\begin{array}{c}5.5 \\
( \pm 0.14)\end{array}$ & $\begin{array}{c}5.9 \\
( \pm 0.08\end{array}$ & $\begin{array}{c}5.4 \\
( \pm 0.15)\end{array}$ & $\begin{array}{c}5.9 \\
( \pm 0.09)\end{array}$ & $\begin{array}{c}5.5 \\
( \pm 0.14)\end{array}$ & $\begin{array}{c}5.9 \\
( \pm 0.11)\end{array}$ & $5.6( \pm 0.10)$ & $\begin{array}{c}5.8 \\
( \pm 0.42)\end{array}$ & $4.5( \pm 0.45)$ \\
\hline $\begin{array}{l}\text { Poaching } \\
\left(R^{2}=0.181\right)\end{array}$ & $\begin{array}{c}5.3 \\
( \pm 0.09)\end{array}$ & $\begin{array}{c}4.1 \\
( \pm 0.16)^{\star \star}\end{array}$ & $\begin{array}{c}4.9 \\
( \pm 0.10)\end{array}$ & $\begin{array}{c}4.9 \\
( \pm 0.16)\end{array}$ & $\begin{array}{c}5.3 \\
( \pm 0.09)\end{array}$ & $\begin{array}{c}4.2 \\
( \pm 0.15)^{\star \star}\end{array}$ & $\begin{array}{c}5.4 \\
( \pm 0.12)\end{array}$ & $4.6( \pm 0.11)^{\star \star}$ & $\begin{array}{c}4.6 \\
( \pm .43)\end{array}$ & $3.6( \pm 0.34)$ \\
\hline $\begin{array}{l}\text { Pest control } \\
\left(R^{2}=0.209\right)\end{array}$ & $\begin{array}{c}4.8 \\
( \pm 0.10)\end{array}$ & $\begin{array}{c}3.4 \\
( \pm 0.17)^{\star \star}\end{array}$ & $\begin{array}{c}4.6 \\
( \pm 0.11)\end{array}$ & $\begin{array}{c}4.1 \\
( \pm 0.19)\end{array}$ & $\begin{array}{c}4.9 \\
( \pm 0.11)\end{array}$ & $\begin{array}{c}3.5 \\
( \pm 0.15)^{\star \star}\end{array}$ & $\begin{array}{c}4.9 \\
( \pm 0.13)\end{array}$ & $4.0( \pm 0.13)^{\star}$ & $\begin{array}{c}4.7 \\
( \pm 0.52)\end{array}$ & $2.4( \pm 0.28)$ \\
\hline $\begin{array}{l}\text { Pet trade } \\
\left(R^{2}=0.151\right)\end{array}$ & $\begin{array}{c}4.7 \\
( \pm 0.11)\end{array}$ & $\begin{array}{c}3.7 \\
( \pm 0.16)^{\star}\end{array}$ & $\begin{array}{c}4.4 \\
( \pm 0.11)\end{array}$ & $\begin{array}{c}4.2 \\
( \pm 0.17)\end{array}$ & $\begin{array}{c}4.7 \\
( \pm 0.11)\end{array}$ & $\begin{array}{c}3.6 \\
( \pm 0.16)^{\star \star}\end{array}$ & $\begin{array}{c}4.9 \\
( \pm 0.13)\end{array}$ & $3.9( \pm 0.12)^{\star \star}$ & $\begin{array}{c}4.8 \\
( \pm 0.55)\end{array}$ & $2.8( \pm 0.31)$ \\
\hline $\begin{array}{l}\text { Road/Railroad } \\
\text { kill } \\
\left(R^{2}=0.057\right)\end{array}$ & $\begin{array}{c}4.7 \\
( \pm 0.10)\end{array}$ & $\begin{array}{c}4.1 \\
( \pm 0.15)^{\star \star}\end{array}$ & $\begin{array}{c}4.4 \\
( \pm 0.10)\end{array}$ & $\begin{array}{c}4.8 \\
( \pm 0.14)^{\star \star}\end{array}$ & $\begin{array}{c}4.7 \\
( \pm 0.10)\end{array}$ & $\begin{array}{c}4.3 \\
( \pm 0.15)\end{array}$ & $\begin{array}{c}4.8 \\
( \pm 0.12)\end{array}$ & $4.4( \pm 0.11)$ & $\begin{array}{c}4.6 \\
( \pm 0.43)\end{array}$ & $4.5( \pm 0.33)$ \\
\hline $\begin{array}{l}\text { Window } \\
\text { strikes } \\
\left(R^{2}=0.129\right)\end{array}$ & $\begin{array}{c}4.3 \\
( \pm 0.10)\end{array}$ & $\begin{array}{c}3.3 \\
( \pm 0.16)^{\star \star}\end{array}$ & $\begin{array}{c}4.0 \\
( \pm 0.11)\end{array}$ & $\begin{array}{c}3.9 \\
( \pm 0.16)\end{array}$ & $\begin{array}{c}4.3 \\
( \pm 0.10)\end{array}$ & $\begin{array}{c}3.4 \\
( \pm 0.15)^{\star \star}\end{array}$ & $\begin{array}{c}4.4 \\
( \pm 0.12)\end{array}$ & $3.7( \pm 0.12)^{\star}$ & $\begin{array}{c}4.6 \\
( \pm 0.41)\end{array}$ & $2.2( \pm 0.32)^{\star \star}$ \\
\hline $\begin{array}{l}\text { Sport hunting } \\
\left(R^{2}=0.245\right)\end{array}$ & $\begin{array}{c}4.3 \\
( \pm 0.11)\end{array}$ & $\begin{array}{c}2.8 \\
( \pm 0.18)^{\star \star}\end{array}$ & $\begin{array}{c}4.0 \\
( \pm 0.12)\end{array}$ & $\begin{array}{c}3.6 \\
( \pm 0.19)\end{array}$ & $\begin{array}{c}4.4 \\
( \pm 0.11)\end{array}$ & $\begin{array}{c}2.7 \\
( \pm 0.16)^{\star \star}\end{array}$ & $\begin{array}{c}4.6 \\
( \pm 0.14)\end{array}$ & $3.3( \pm 0.13)^{\star \star}$ & $\begin{array}{c}4.2 \\
( \pm 0.52)\end{array}$ & $1.3( \pm 0.14)^{\star \star}$ \\
\hline $\begin{array}{l}\text { Cat predation } \\
\left(R^{2}=0.055\right)\end{array}$ & $\begin{array}{c}3.8 \\
( \pm 0.11)\end{array}$ & $\begin{array}{c}3.7 \\
( \pm 0.18)\end{array}$ & $\begin{array}{c}3.6 \\
( \pm 0.11)\end{array}$ & $\begin{array}{c}4.0 \\
( \pm 0.18)^{\star}\end{array}$ & $\begin{array}{c}3.5 \\
( \pm 0.11)\end{array}$ & $\begin{array}{c}4.1 \\
( \pm 0.17)^{\star \star}\end{array}$ & $\begin{array}{c}3.9 \\
( \pm 0.14)\end{array}$ & $3.6( \pm 0.13)$ & $\begin{array}{c}3.5 \\
( \pm 0.58)\end{array}$ & $3.6( \pm 0.43)$ \\
\hline $\begin{array}{l}\text { Relocation } \\
\left(R^{2}=0.103\right)\end{array}$ & $\begin{array}{c}3.5 \\
( \pm 0.11)\end{array}$ & $\begin{array}{c}2.5 \\
( \pm 0.15)^{\star \star}\end{array}$ & $\begin{array}{c}3.2 \\
( \pm 0.17)\end{array}$ & $\begin{array}{c}3.2 \\
( \pm 0.17)\end{array}$ & $\begin{array}{c}3.4 \\
( \pm 0.11)\end{array}$ & $\begin{array}{c}2.7 \\
( \pm 0.15)\end{array}$ & $\begin{array}{c}3.6 \\
( \pm 0.13)\end{array}$ & $2.9( \pm 0.11)^{\star}$ & $\begin{array}{c}4.0 \\
( \pm 0.56)\end{array}$ & $2.2( \pm 0.35)$ \\
\hline $\begin{array}{l}\text { Spearman } \\
\text { rank order }^{b}\end{array}$ & $r_{\mathrm{s}}=$ & $.89 * *$ & $r_{\mathrm{s}}=$ & $.96^{\star \star}$ & $r_{\mathrm{s}}=$ & $86^{\star \star}$ & & $=0.96^{\star \star}$ & & $0.69 * *$ \\
\hline
\end{tabular}

$R^{2}=$ Adjusted coefficient of determination, $P<0.01$ in all cases.

${ }^{*} P<0.05,{ }^{* *} P<0.01$ : significance of rank-order correlation coefficients and of differences between two groups in each $t$-test comparison.

${ }^{a}$ Hierarchical regression with variables entered in above order accounts for effects of previous variable. For example, a significant difference between urban and rural residents was after adjustment for gender, while a significant difference based on wildlife value orientation was after adjustment for all other variables in model.

${ }^{b}$ Spearman rank order correlation coefficients of mean scores for the 12 activities by the two groups in each comparison.

${ }^{c}$ Subset of $n=147$ strongly animal welfare-oriented participants.

${ }^{\mathrm{d}}$ Subset of $\mathrm{n}=192$ strongly conservation-oriented participants. 


\section{Analysis}

The variable wildlife engagement level (high or low) was determined by participants' responses to questions about their professional and unpaid activities, including their roles and the duration of their involvement. Participants who self-identified as wildlife professionals or enthusiasts were verified for the designation of 'high engagement' by checking that they were involved for at least three years as a paid professional or five years as an unpaid enthusiast. Demographic characteristics of participants who did not self-identify as wildlife professionals or enthusiasts were reviewed, and all participants who met the above criteria for 'high engagement' were classified as such, while all others were classified as 'low engagement'.

The wildlife value orientation of participants was designated as either conservation-oriented or welfareoriented based on the wildlife activities they enjoyed, the organisations they supported, and themes from their responses to the three lead-up questions on harms, as assessed by inductive content analysis (Elo \& Kyngäs 2008). The conservation-oriented group included individuals who hunted or trapped, and/or supported hunting, land preservation or conservation organisations, and/or who expressed most concern about effects on ecosystems and populations in their open-ended responses. The welfare-oriented group did not hunt or trap, supported animal welfare organisations and/or focused on harm to individual animals in their open-ended responses. Individuals who supported both conservation and animal welfare organisations, or neither, were classified by themes identified in their responses to the open-ended questions.

Means and standard errors of the harm scores were calculated by demographic group for each of the 12 human activities and Spearman correlations were calculated between the two groups for each variable tested. The harm scores, treated as a continuous dependent variable, were analysed by hierarchical regression in SPSS to determine significant demographic predictors (Vaske 2008). All binomial independent variables were entered into the model in the following a priori order such that each variable was tested after taking the effect of the preceding variable(s) into account: gender, residency (urban or rural), wildlife engagement level, and wildlife value orientation.

A subset of participants with the most contrasting wildlife value orientations was also analysed. This included the 22 most conservation-oriented participants, all of whom reported that they hunt or trap, support land preservation and hunting/trapping organisations, and do not support any animal welfare or animal rights organisations. Also included were the eleven most welfare-oriented participants, all of whom reported that they support animal welfare and animal rights organisations, do not support land preservation or hunting/trapping organisations, and do not hunt or trap. Mean harm scores were calculated for these two groups and a Spearman correlation compared their rankings of the 12 activities.

\section{Results}

A total of 339 British Columbians participated in the main research question of the survey. These included 229 females, 105 males and 5 participants who did not indicate gender. Age ranges were 19-29 (14\%), 30-39 (22\%), 40-49 (18\%), 50-59 (27\%), and 60-above (17\%), with five who did not indicate age. Participants divided as 227 urban and 112 rural residents, while 227 were designated as 'low engagement' with wildlife and 112 were designated as 'high engagement'. For wildlife value orientation, 192 participants were classified as conservation-oriented and 147 as welfare-oriented.

Across all groups, including conservation-oriented and welfare-oriented participants, the four human activities that destroy or alter habit (urban development, pollution, resource development, agriculture) were consistently rated as most harmful to wildlife and were ranked in the same order (Table 2). Activities 
that cause direct and intentional harm (poaching, pest control, pet trade, sport hunting) generally received moderate harm scores, while unintentional harms (road/railroad kill, window strikes, cat predation, relocation) were scored slightly lower. Rankings of the 12 activities were highly consistent among demographic groups tested. Spearman rank order correlation coefficients showed almost perfect agreement between conservation-oriented and welfare-oriented participants $\left(r_{\mathrm{s}}=0.96, P<0.01\right)$ and between urban and rural participants $\left(r_{\mathrm{s}}=0.96, P<0.01\right)$ (Table 2). Agreement was also high between female and male participants $\left(r_{\mathrm{s}}=0.89, P<0.01\right)$ and between high and low engagement groups $\left(r_{\mathrm{s}}=\right.$ $0.86, P<0.01$ ) (Table 2).

Despite similar rankings, there were some differences in the level of harm attributed to activities by the different groups. Compared to men, women consistently rated the 12 activities as more harmful, with the largest difference seen in sport hunting (Table 2). Urban residents rated most activities as slightly more harmful than did rural residents, with the exception of cat predation and road/railroad kill, which rural residents rated as significantly more harmful than their urban counterparts (Table 2). Individuals with low wildlife engagement rated all activities as more harmful to wildlife compared to those with high engagement levels, with the exception of cat predation (Table 2). Harm scores of welfare-oriented participants were consistently higher than those of conservation-oriented participants, with the largest differences $(P<0.01)$ seen in poaching, pet trade and sport hunting (Table 2). Of the 12 activities, relocation received the lowest ranking of harm across all groups. Based on qualitative comments, it seems the term was variously understood to mean introduction of invasive species, relocation of problem animals, and movement of native species within their range.

The subset of 22 strongly conservation-oriented and eleven strongly welfare-oriented participants were also similar to each other in their relative rankings $\left(r_{\mathrm{s}}=0.69, P<0.05\right)$. The four activities that destroy or alter habit (urban development, pollution, resource development, agriculture) were ranked highest by both groups, with conservation-oriented participants also ranking road/rail kill as harmful as agriculture (Table 2). Despite the overall similarity, the welfare-oriented participants rated direct killing activities (sport hunting, pest control, pet trade, poaching) as more harmful than the conservation-orientated participants. Welfare-oriented participants also ranked cat predation as least harmful of all 12 activities, whereas the strongly conservation-oriented participants ranked cat predation as the sixth most harmful activity.

In the hierarchical regression analysis, the regression model of the four demographic variables (gender, residency, wildlife engagement level, wildlife value orientation) accounted for significant variation in harm scores for all 12 activities. However, the percentage of variance explained (expressed as $R^{2}$ values in Table 2) ranged from a very low $5.5 \%$ for cat predation, to a moderate $24.5 \%$ for sport hunting. Collinearity tolerance and variance inflation factor values were $>0.1$ and $<10$, respectively, for all tested variables across all activities, and therefore no collinearity was deemed to be present.

Gender was a significant predictor of increased harm scores for all activities except agriculture and cat predation (Table 2). Residency was a significant predictor of harm scores for these two activities, with rural areas scoring harm higher, as well as for pollution and road/railroad kill. Wildlife engagement level was a significant predictor of harm scores for eight activities, with low engagement participants scoring harm higher, but not for urban development, agriculture road/rail kill, and relocation. Wildlife value orientation was a significant predictor for half of the activities, but not for the four highest ranked activities (Table 2).

\section{Discussion}

This study was not designed to provide a random or representative sample, but to compare differences between groups, who hold primarily conservation values versus those who align primarily with animal 
welfare values. The online engagement tool attracted a wide distribution of ages and wildlife experience, an urban-to-rural ratio (2:1) that over-represented rural populations in the province (rural population = $14 \%$ of provincial population; Government of Canada 2005), and a high female demographic, in contrast to traditional wildlife surveys which are often gender-biased toward males (Jacobson et al 2007).

It was not expected that the harm scores would necessarily agree with expert or empirically correct ratings of harm. For example, window strikes received relatively low ratings, whereas Klem (1990) concluded, on the basis of extensive research, that windows are an extremely important hazard to birds. Interestingly, all groups rated road/railroad kill as more important than sport hunting, in line with the expert conclusion of Forman and Alexander (1998) that roads and vehicles have eclipsed hunting as the leading direct human cause of death to vertebrates in North America. Further, respondents may have rated harms differently among species if specific examples were used, however a dozen echoed this respondent's view:

These answers would change if targeted towards a certain species or group of species but they are listed as I see it for overall number of animal globally.

\section{Conservation and welfare views on harms to wildlife}

If the concerns of participants were affected only by a conservation or animal welfare focus, then we would expect those with welfare orientations to give the highest scores to activities that harm individual animals based on the number of animals affected, the nature and duration of the harm, and the capacity of the animals to suffer (Kirkwood et al 1994); whereas participants with conservation orientations would give the highest scores to activities that harm populations, species, or ecological systems, without consideration for harms to individuals. However, our results indicate that the two groups were in almost complete agreement regarding the relative importance of the various activities, ranking the 12 activities in almost the identical order and identifying the same four activities (urban development, pollution, resource development, agriculture) as most harmful to wildlife.

In the full sample, however, it is conceivable that extreme conservation or welfare views were diluted by the inclusion of many less-polarised participants in the two categories. The subset of the most extreme conservation-oriented and welfare-oriented participants was examined to test this possibility. Even in these polarised groups, however, there was still significant agreement on the relative importance of activities, with top rankings given by both groups to the four activities that destroy or alter habitat.

Human activities have been classified as affecting wildlife either directly or indirectly and either intentionally or unintentionally (Fraser \& MacRae 2011; Fraser 2012). In this study, indirect and unintentional harms to animals (resulting from habitat alteration and pollution) were scored as most harmful by all groups. These harms may stand out because they have enduring impacts by changing physical, chemical and biological environments, affecting wild animals throughout their lives, and affecting both current and future generations. Further, such harms may affect a wide range of taxa and at all levels, including individuals, populations and ecosystems. The fact that both conservation-oriented and welfareoriented groups ranked these types of harms highest suggests scope for broad agreement that may be missed when the groups disagree on specific issues or management actions.

Activities that cause direct harm to wildlife - such as poaching, pest control, pet trade, road/railroad kill, sport hunting - were generally rated more moderately by all groups. The moderate harm level may have been assigned to these activities because they tend to inflict harm on only current generations, may be limited to small portions of the animal's life and apply to only certain species groups. Direct harms may also have received only moderate harm scores because they are generally open to control and 
management. In contrast, indirect and unintentional harms to animals, for example from urbanisation and pollution, provide little scope for control over the eventual effects on animals.

Demographic influence on views of harm

Although the different demographic groups ranked harms in a very similar order, the level of harm attributed to activities was consistently higher for certain groups than others. Firstly, women in this survey scored all activities as more harmful than men did, the effect of gender being strongest for activities that involve direct killing. Many studies on the attitudes and values of wildlife stakeholders have also demonstrated differences between men and women (eg Czech et al 2001; Zinn \& Pierce 2002), with women showing greater opposition to activities that pose potential harm to animals (Kellert \& Berry 1987). Women are typically under-represented as wildlife stakeholders because they participate less often than men in traditional conservation activities, and thus their views are often missed in standard surveys of licensees, such as hunters and trappers. Rural or urban residency is often used to contrast attitudes and values towards wildlife (Kellert 1976; Heberlein \& Ericsson 2005). However, residency is becoming more fluid as many people who grew up in rural areas move into urban areas and some urban residents relocate to a rural lifestyle (Messmer 2000). Differences were small in this survey, with urban residents scoring harm slightly higher than rural residents for all activities except cat predation and road/railroad kill. These two activities may have been perceived as more harmful by rural residents because of higher wildlife populations in rural areas and rural residents' greater appreciation of the effects of these unintentional harms (Messmer 2000). Alternatively, road kill and victims of cat predation may be less noticeable in urban areas due to city services.

Highly engaged professionals and enthusiasts - a group generally supportive of using sport hunting as a conservation tool - are traditionally those who influence wildlife policy. In contrast, low-engagement and animal welfare-oriented participants assigned significantly higher harm scores to all forms of intentional killing. Wildlife managers should take into consideration the influence of these variables in addition to possible gender and residency effects.

Animal welfare implications

Given the broad agreement on ranking activities that harm wildlife, wildlife managers should be able to develop management actions that address broadly held priorities, including the priorities of both conservation-oriented and welfare-oriented citizens. Further, considerations can be made for the generally higher harm scores towards direct killing activities, by inclusion of groups not traditionally consulted about wildlife management (women, low-engagement, and welfare-oriented). Here, managers need to consult broadly to ensure that specific policy decisions are aligned with diverse and widely held public values.

\section{Acknowledgements}

We are grateful to all participants and to the organisations which distributed the survey through their membership lists. We also thank Peter Danielson and his research team at the W Maurice Young Centre for Applied Ethics for valuable assistance in survey design and programming, Catherine Schuppli for advice during data collection and retrieval and the Animal Welfare referees for constructive comments. Funding was provided by the Social Sciences and Humanities Research Council of Canada. 


\section{References}

Ahmad R, Bailey J, Bornik Z, Danielson P, Dowlatabadi H, Levy E and Longstaff H 2006 A web-based instrument to model social norms: NERD survey design and results. The Integrated Assessment Journal 6: 9-36

British Columbia Ministry of Environment 2011 Conservation Framework. http://www.env.gov.bc.ca/conservationframework/

Callicott JB 1989 In Defense of the Land Ethic: Essays in Environmental Philosophy. State University of New York Press: Albany, USA

Curnutt J 1996 How to argue for and against sport hunting. Journal of Social Philosophy 27: 65-89. http://dx.doi.org/10.1111/j.1467-9833.1996.tb00238.x

Czech B, Devers PK and Krausman PR 2001 The relationship of gender to species conservation attitudes. Wildlife Society Bulletin 29: 187-194

Dubois S and Fraser D 2003 Conversations with stakeholders 1: Goals, impediments, and relationships in wildlife rehabilitation. Journal of Wildlife Rehabilitation 26: 14-22

Elo S and Kyngäs SH 2008 The qualitative content analysis process. Journal of Advanced Nursing 62: 107-115. http://dx.doi.org/10.1111/j.1365-2648.2007.04569.x

Forman RTT and Alexander LE 1998 Roads and their major ecological effects. Annual Review of Ecology and Systematics 29: 207-231. http://dx.doi.org/10.1146/annurev.ecolsys.29.1.207

Fraser D 2008 Understanding Animal Welfare: The Science in its Cultural Context. Wiley-Blackwell: Oxford, UK

Fraser D 2010 Toward a synthesis of conservation and animal welfare science. Animal Welfare 19: 121124.

Fraser D 2012 A 'practical' ethic for animals. Journal of Agricultural and Environmental Ethics 25: 721746. http://dx.doi.org/10.1007/s10806-011-9353-z

Fraser D and MacRae AM 2011 Four types of activities that affect animals: implications for animal welfare science and animal ethics philosophy. Animal Welfare 20: 581-590

Fulton GR and Ford HA 2001 The conflict between animal welfare and conservation. Pacific Conservation Biology 7: 152-153

Gallup 2010 Flash Eurobarometer No 290 Attitudes towards biodiversity. http://ec.europa.eu/public_opinion/flash/fl_290_en.pdf

Government of British Columbia 2012a Wildlife http://www.bclaws.ca/EPLibraries/bclaws_new/document/ID/freeside/00_96488_01

Government of British Columbia 2012b Prevention of Cruelty to Animals Act. http://www.bclaws.ca/EPLibraries/bclaws_new/document/ID/freeside/00_96372_01

Government of Canada 2005 Rural British Columbia profile: a ten-year census analysis (1991-2001). http://www.rural.gc.ca/RURAL/display-afficher.do?id=1245089374518\&lang=eng 
HarrisDecima 2010 World Society for the Protection of Animals. Humane treatment of animals survey. http://www.wspa.ca/documents/WSPA-HumaneTreatmentofAnimalsExecutive Summary.pdf

Heberlein TA and Ericsson G 2005 Ties to the countryside: accounting for urbanites attitudes toward hunting, wolves, and wildlife. Human Dimensions of Wildlife 10: 213-227. http://dx.doi.org/10.1080/10871200591003454

Hutchins M 2007 The limits of compassion. The Wildlife Professional 1: 42-44. http://dx.doi.org/10.4004/1933-2866(2007)1[42:TLOC]2.0.CO;2

Jacobson CA, Brown TL and Scheufele DA 2007 Gender-biased data in survey research regarding wildlife. Society \& Natural Resources 20: 373-377. http://dx.doi.org/10.1080/08941920601161387

Kellert SR 1976 Perceptions of animals in American society. Transactions of the North American Wildlife and Natural Resources Conference 41: 533-545

Kellert SR and Berry JK 1987 Attitudes, knowledge, and behaviors toward wildlife as affected by gender. Wildlife Society Bulletin 15: 363-371

Kirkwood JK and Sainsbury AW 1996 Ethics of interventions for the welfare of free-living wild animals. Animal Welfare 5: 235-243

Kirkwood JK, Sainsbury AW and Bennett PM 1994 The welfare of free-living wild animals: methods of assessment. Animal Welfare 3: 257-273

Klem D Jr 1990 Collisions between birds and windows: mortality and prevention. Journal of Field Ornithology 61: 120-128

Kuhnen VV, Remor JO and Lima REM 2012 Breeding and trade of wildlife in Santa Catarina state, Brazil. Brazilian Journal of Biology 72: 59-64. http://dx.doi.org/10.1590/S1519-69842012000100007

Longcore T, Rich C and Sullivan LM 2009 Critical assessment of claims regarding management of feral cats by Trap-Neuter-Return. Conservation Biology 23: 887-894. http://dx.doi.org/10.1111/j.15231739.2009.01174.x

Massei G, Quy RJ, Gurney J and Cowan DP 2010 Can translocations be used to mitigate human-wildlife conflicts? Wildlife Research 37: 428-439. http://dx.doi.org/10.1071/WR08179

Messmer T 2000 The emergence of human-wildlife conflict management: turning challenges into opportunities. International Biodeterioration and Biodegradation 45: 97-102. http://dx.doi.org/10.1016/S0964-8305(00)00045-7

Perry D and Perry G 2008 Improving interactions between animal rights groups and conservation biologists. Conservation Biology 22: 27-35. http://dx.doi.org/10.1111/j.1523-1739.2007.00845.x

Regan T 1983 The Case for Animal Rights. University of California Press: Berkeley, USA

Sainsbury AW, Bennett PM and Kirkwood JK 1995 The welfare of free-living wild animals in Europe: harm caused by human activities. Animal Welfare 4: 183-206 
Salafsky N, Salzer D, Stattersfield AJ, Hilton-Taylor C, Neugarten R, Butchart SHM, Collen B, Cox N, Master LL, O'Connor S and Wilkie D 2008 A standard lexicon for biodiversity conservation: unified classifications of threats and actions. Conservation Biology 22: 897-911. http://dx.doi.org/10.1111/j.15231739.2008.00937.x

Schmidt RH 1990 Why do we debate animal rights? Wildlife Society Bulletin 18: 459-461

Soulé ME 1985 What is conservation biology? BioScience 35: 727-734. http://dx.doi.org/10.2307/1310054

The Wildlife Society (TWS) 2011 Animal Rights Position Statement. http://joomla.wildlife.org/documents/positionstatements/animal_rights_8.30.2011.pdf

Wimberger K, Downs CT and Boyes RS 2010 A survey of wildlife rehabilitation in South Africa: is there a need for improved management? Animal Welfare 19: 481-499

Woods M, McDonald RA and Harris S 2003 Predation of wildlife by domestic cats (Felis catus) in Great Britain. Mammal Review 33: 174-188. http://dx.doi.org/10.1046/j.1365-2907.20 03.00017.x

Vaske JJ 2008 Survey research and analysis: applications in parks, recreation and human dimensions. Venture Publishing Inc, State College: Pennsylvania, USA

Zinn HC and Pierce CL 2002 Values, gender, and concern about potentially dangerous wildlife. Environment and Behavior 34: 239-256. http://dx.doi.org/10.1177/0013916502034002005 